\title{
The taught curriculum of moral education at Japanese elementary school: the role of classtime in the broad curriculum
}

\author{
Sam Bamkin \\ Graduate School of Education, University of Tokyo, Japan
}

\begin{abstract}
The school curriculum in Japan provides for moral education. Teachers' educational practice is influenced by the written curriculum, and must be organised around its audited requirements. However, it may diverge from aspects of what the curriculum prescribes. Though previous studies have explored pedagogic beliefs and spontaneous practices, few have considered pedagogic planning in the context of the written curriculum. Drawing on classroom observations and interviews with teachers and educators, this study seeks to understand the taught curriculum of moral education in Japan: how it is structured "on the ground" and how schools and teachers plan moral education. Moral education classtime (moral education in the narrow sense) emerges as a site for reflection and pre-learning which supports the learning of prosocial behaviour (moral education in the broad sense), which is planned primarily through other educational activities. Understanding these intracurricula relations addresses long-standing questions in the study of Japanese education. It also holds significance for the development of theory in pedagogy for moral education, suggesting new directions for moral education in intra-curricular connection and planning incidental learning.
\end{abstract}

\section{ARTICLE HISTORY}

Received 12 June 2019

Accepted 11 Jan 2020

\section{KEYWORDS}

Japanese education; moral education; dōtoku; taught curriculum; hidden curriculum; policy implementation

\section{Introduction}

The school curriculum in Japan provides for moral education. This includes principles and aims, moral education classtime, and other school activities. However, though teachers' educational practice is influenced by the written curriculum and must be organised around its audited requirements, it may diverge from aspects of what the curriculum prescribes (see Lipsky, 1980; McLaughlin, 1987; Jackson, 1992; Ball, 1994 on theory; Cave, 2016; Bjork, 2016 on Japanese education practice in reform; Bamkin, 2018 on reform of moral education in Japan). Therefore, rather than relying on official documents, the implementation of moral education in classrooms and schools - how the written curriculum is transformed into a taught curriculum - warrants examination.

This study seeks to understand the structure of the taught curriculum of moral education at Japanese elementary schools. How do teachers plan moral education and how do 
they theorise its effectiveness in influencing everyday behaviour outside the school? How do general teaching practices for moral development interact or fit in with curriculum requirements for dedicated classtime? Research on Japanese education has noted a complex relationship between the narrow sense of moral education as classtime or subject, and the broader sense of moral education as pedagogic practice to promote prosocial behaviour (Bamkin, 2019, p. 258; Bolton, 2015, p. 4; Cave, 2007; Poukka, 2011, pp. 197-210). However, little progress has been made unpacking the nature of this relationship. Addressing such questions is important to understand the extent to which dedicated classtime is seen by teachers to contribute to moral education; how the taught curriculum is structured; and the boundary between the planned and unplanned. Likewise, domestic academic interest in moral education has increased recently because of reforms (MEXT, 2015) that are currently taking effect. Though this study does not aim to address the important topic of curriculum reform, its account of the taught curriculum immediately before the reforms were announced provides an important baseline for such future research. Indeed, though aspects of the broader school experience have been examined, no account of classroom practice of Japanese moral education classes yet exists in English.

It is surprising that research on moral education has not turned more extensively to the Japanese case since moral education forms a topic of professional discourse in Japan, discussed regularly by teachers (and by policy-makers, parents and, to some extent, children). Education itself is an inherently moral enterprise (Arthur et al., 2016, p. 1; Damon, 2008, pp. 131-2; DeVries \& Zan, 1994, p. 2; Hansen, 2001; Jackson et al., 1993; Noddings, 2013), occurring in every class and school interaction globally. Thus, the significance of Japan in building theory is not because moral education occurs, but because specifically in Japan a considerable part of its occurrence is deliberated and planned. It is discussed as a regular topic amongst educational professionals, providing a common professional language, not distantly academical to teachers and educators. Although moral education is equally as important everywhere and not entirely opaque anywhere, its practice is easier to bring into focus in Japan because more of what teachers bring to the classroom may be expected to be planned. In the UK and USA, one aspect of the concepts of the hidden curriculum that has endured in discussions on the socio-moral domains of learning is that its contents remain hidden from teachers (Giroux \& Purpel, 1983; Jackson, 1992). Needless to say, classroom studies in Japan, too, must remain equally as mindful of hidden elements.

Previous research relevant to education practice in the moral domain in Japan has largely followed a tradition of social anthropology, utilising ethnographic methods to elucidate socialisation that occurs through classroom interactions (e.g. Lewis, 1989, 1995 at preschool; Lewis, 1995; Cave, 2007 at elementary school; Rohlen, 1983; Bjork \& Fukuzawa, 2013 at junior high school). Beginning with the observed experience of children and with interviews, these studies provide insight into moral dispositions and spontaneous decisions of teachers, to converge on sets of implicit beliefs and practice (Tobin et al., 2009) that inform classroom practice. These implicit beliefs and practices are important to understand the social development of children, and perhaps mainstream school culture. However, questions remain on how such practices are structured in relation to the written curriculum, and the extent to which moral education is planned.

Other studies have addressed specific debates which relate to moral development. Cave's (2007) study of the formation of selfhood at Japanese elementary school examines how the balance between independence and social interdependence are implemented in 
practice, dealing seriously with beliefs, practices, justifications and aspirations of two classroom teachers through observation and in-depth interviewing. Amongst other findings, Cave provides insight into how teachers balance policy demands to further foster individuality with established practices encouraging empathy to underpin and promote interdependence. The study is powerful in providing both an outline of the moral atmosphere (DeVries \& Zan, 1994) at Japanese elementary school, and also in elucidating practices that may develop students' conceptions of the self in the minutiae of academic classes and ceremonies. In comparison, the current study takes a broader perspective on teacher's conceptions of moral education, utilising interviews that do not reach the depth of a full case study such as that undertaken by Cave.

It is easy to imagine that moral education, as classtime or subject, serves as the primary vehicle for moral education. Various theoretical approaches to character education and moral education (in the broad sense) have advocated the allocation of classtime, whilst others have emphasised the importance of "school culture" and means of teaching (see Berkowitz \& Bier, 2005 for a review; Sanger \& Osguthorpe, 2005 on difficulties categorising approaches). On the other hand, many analyses of Japanese curricula and textbooks have overlooked the possibilities for unwritten aspects of the curriculum and intra-curriculum connections, assuming lessons of direct instruction in values or morality. This not only conflates policy with practice (Bamkin, 2019), but also overlooks complexity. Despite knowledge on school culture gleaned from studies on the curriculum as experienced, the taught curriculum remains under-studied in relation to moral education.

To understand teachers' planning of moral education, this study begins with teachers' practice, considering the taught curriculum. Drawing on classroom observations and interviews with teachers and educators in Japan, the view that emerges presents moral education classtime as a site for reflection which in turn supports the learning of prosocial behaviour, itself planned primarily through other educational activities. This analysis holds significance for researchers of Japanese education. It also holds significance, as a case study, for moral education theory, particularly in suggesting new directions which have thus far received little attention, since the context is structurally and culturally different from the majority of data informing theory thus far, which has tended to be Anglophone and Western.

\section{Moral education: Broad and narrow conceptions}

Centrally planned moral education in Japan began prior to the first nation-wide school system of the Meiji restoration, initially utilising translated moral readers from the UK and other Western countries (Nakano, 1989). These coursebooks included Western ideas on character traits, social duties and individual rights, and may have introduced the "great person" teaching approach, still popular today (Kaizuka, 2009; Roesgaard, 2016). A state textbook was introduced some years later and revised under Confucianist principles in line with the 1890 Imperial Rescript on Education. ${ }^{1}$ The official textbooks became increasingly, though erratically, militant in statist instruction in the years between the Russo-Japanese

\footnotetext{
${ }^{1}$ I use the term coursebook to describe unregulated books available on the open market, equivalent to modern-day fukudokuhon; and textbooks to refer (historically) to mandated books and (currently) to books approved by the Ministry of Education to form a limited range of options for mandatory usage, both called kyōkasho.
} 
War and the Asia-Pacific War. At least as early as 1912 (Sawayanagi, as cited in Nakano, 1989, pp. 29-30), there had emerged a counter movement advocating "moral education relevant to children's everyday lives." This movement ran counter to education for political advantage of the state, advocating moral education that begins and expands from concrete interests of the child in the progressive tradition, with resonances of humanism. Ministry of Education documents have drawn partly on this approach to moral education since the first written curriculum.

The curriculum current in 2015 described the aim of moral education, ${ }^{2}$ in the broad sense, as:

to cultivate morality in virtues such as feeling, judgement, attitude and the will to actively contribute. [...] This aim should be taken into account when planning all lesson content and School Activities to enrich it through deeply integrated, structured and developmental supervision to additionally deepen thinking on autonomous living and consciousness of moral values to underpin application in real life (MEXT, 2008).

Many academics (Kaizuka, 2016, p. 70; Nishimura, 2016, p. 175) and teachers (Bamkin, 2016) agree that the purpose of moral education is to develop students' knowledge, competence and practice to live better alongside others. Since 2015, this has been formalised in the written curriculum:

"whilst considering one's own lifestyle," moral education "aims to cultivate morality that serves as the foundation for living better with other people as an autonomous human being, and acting with responsible judgment."

Similar expressions also arise at numerous points in the curriculum, including for special activities. ${ }^{3}$ At least since the first official post-war curriculum of 1951, moral education, as a broad concept, has been prescribed to run through all curriculum subjects and educational activities in school life (Kotera, 2016, p. 49). Its implementation is intended to be diffuse.

In addition to academic subjects, physical education, ${ }^{4}$ integrated studies and moral education classtime, the curriculum allocates time to special activities. The curriculum domain of special activities includes participation in assemblies, lunchtime, cleaning, school trips, sports days, ceremonies and activities at the school's discretion. Special activities are intended to:

aim for holistic development and the expansion of individuality through desirable group activities, to develop an independent, practical attitude of wanting to build a better life through relationships between the self and the group and between the self and society, to deepen self-awareness of living as a human and to cultivate the ability of self-fulfilment (MEXT, 2008).

The aim of learning to live a better life is shared between special activities and moral education as understood by practitioners. In both cases, however, the meaning of "living

\footnotetext{
${ }^{2}$ Due to limited space, only a brief overview of the written curriculum is provided.

${ }^{3}$ For example "to fulfil individual roles to develop better human relations and to improve one's way of living" and "to recognise new topics and issues to improve one's way of living" in both special activities' in Special activities; and "develop bravery and strength to actively live life in a better way" in home economics (MEXT, 2017). The latter example appears, in a similar form, in the prior curriculum (2008).

${ }^{4}$ The relationship between moral education and physical education (or sport) is also regularly described as complex, but remains largely unstudied in the academic literature.
} 
a better life" requires examination, emphasising that it is the interpretation of the school or teacher within their structural confines that delivers the taught curriculum.

Since 1958, the curriculum has further prescribed classtime specifically for the study of moral education, undertaken for approximately one hour per week. The curriculum has long framed moral education classtime as a narrow domain that supports moral learning that occurs through all subjects and school activities. Since 1958 (Eifuku, 2018), it has been charged with "supplementing, deepening and integrating [with] other subjects [...] and educational activities where time is insufficient in their time allocation." Since 2008, moral education classtime has additionally been described as "the cornerstone of moral education" - that the narrow sense of moral education provides a foundation for the broader sense to function. A textual reading of the written curriculum thus remains unclear whether moral education classtime is supportive of other subjects or provides a foundation on which other activities are based. Promoting the new curriculum, Nishino (2017) suggested on the one hand that "Japan has traditionally fostered a whole-school approach to moral education with a class for moral education at its core" (p. 46), whilst listing one of the challenges of curriculum change to be "making moral education classtime as the cornerstone of moral education" (pp. 54-5). These two ideas have continued to coexist in the curriculum since 2008. This adds to the complexity of the little-understood relationship between the broad and narrow concepts of moral education, and their relationship to other subjects and school activities.

The (re)introduction of moral education classtime in 1958 reignited a fierce debate about its purpose, benefits and dangers. In the post-war years, the then-powerful Japan Teachers' Union (Nikkyōsō, JTU) campaigned fiercely against ministerial involvement in moral education textbook creation or vetting in the belief that government control over the content of moral education could lead to the inculcation in children of subservience to the state (see Aspinall, 2001; Bamkin, 2019; Tanaka, 2010). Partially as a reaction, governmental guidance accompanying the 1958 curriculum explicitly warned against "preaching" values and against a perceived pre-war (shūshin) didactic style of teaching moral education (Kotera, 2016, p. 52). Concern about any increase in governmental control continued in education circles, and merged with a general scepticism toward nationalistic policies of successive governments (Bamkin, 2018). This and subsequent public debates referring to moral education (dōtoku) remain largely confined to narrow discussions of moral education classtime, its curriculum chapter and coursebooks. Rarely questioned are other curriculum areas that may contribute to moral development. This gap is also apparent in English- and Japanese-language academic debates (Bamkin, 2019).

As a document, the curriculum has evolved and been infused with pedagogic and political discourses and compromises. Therefore, it is difficult to categorise it or to discern a coherent "approach" to moral education. Khan (1997) has convincingly argued that the set of values provided in the curriculum chapter of moral education classtime and coursebooks reflect a Confucian vision of virtue, which has endured through successive revisions since the Meiji Period (late nineteenth century). These are summarised as "thoughtfulness, reverence, tenacity, modesty, magnanimity, progress, patriotism, sincerity and courage" (Khan, 1997, p. 204). In addition, Roesgaard (2016) provides an in-depth analysis of the effects of internationalisation on the moral education curriculum document. The marks of this discourse can be seen in the written curriculum in the values promoting tradition, love of country and respect and understanding of other countries. Karasawa (1955) has shown that marks of Confucianism, nationalism, international exchange and humanism could all be seen to varying degrees in 
textbooks both before and shortly after the war. This may reflect an earlier version of the effects of internationalisation and political compromise on the broader curriculum.

Curriculum studies, however, has shown that documents show only part of what teachers deliver and create in the classroom, or what pupils experience as learning. Ball (1994, 2011) utilises the term "enactment" of policy, rather than "implementation," to emphasise the agency of teachers, who act within the circumstances that it creates, both to fulfil and to change and mediate its implementation. Jackson (1993, p. 42) lists eight aspects of teaching that might be evaluated for moral content, only two of which appear in written form. In Japan, Bolton (2015, pp. 55-6) found that the widely analysed ministryissued coursebook Watashi-tachi no dōtoku was used in only a minority of lessons. My previous research (Bamkin, 2016) found that teachers' aims for broad moral education in Japan are focused differently to intentions expressed in the written curriculum. The majority of teachers interviewed placed "consideration of others" (omoiyari, proactive caring to read and satisfy the needs of others) distinctly as the most important value. This was followed by perseverance (ganbaru). A significant minority of participants identified "comportment and manners" as important. Finally, the study identified "life habits" as an important focus for teachers through classroom observations. My research on the early stages of moral education reform (Bamkin, 2018) found that many Japanese teachers remained critical of curriculum policy in moral education and moreover have confidence in omitting or modifying some content requirements, where they deem doing so important. These studies demonstrate the potential for teachers to interpret the aims of moral education differently from written sources. Despite overlap, policy is mediated by teachers and other education practitioners. Previously, I conducted a critical review of literature delineating how studies drawing only on textbooks, written curriculum and Ministry documents (e.g. Hoffman, 1999; Khan, 1997; Nishino, 2017; Roesgaard, 2016) hold limited power to elucidate the taught curriculum of moral education. In summary:

If policies were simply and perfectly implemented in classrooms, then research on policy [political debate, laws and regulations, curriculum documents, textbooks] would hold educational significance. However, this is not the case. The relationship between policy and practice is complex because policies are mediated by teachers, resources and multiple levels of administration. Whilst policy holds symbolic meaning, and its analysis holds important political significance, it is the analysis of classroom practice that holds educational significance, for it is practice that shapes the lives of individual children (Bamkin, 2019, p. 251).

Currently, only a few studies shed light on moral education practice from either a broad or narrow perspective. Therefore, this article analyses both the broad and the narrow conceptions of moral education as practice in relation to curriculum and theory.

\section{Methodology and context}

This study utilised interviews and classroom observations to understand the practice of moral education. Qualitative data are most suitable to understand the lived practices of professional educators and their reasoning. The primary data were collected between May and August 2015 from individual and small group interviews in nine elementary schools, seven junior high schools and one combined school, located in six municipalities spread across four prefectures (todōfuken) in Japan. The areas ranged from central Tokyo 
wards, to cities in central and west Japan, to small rural municipalities. Fieldwork in each location lasted between one and two weeks, including 10-20 interview participants in each region. Observations of moral education classes, other classes, and educational activities throughout the school day were undertaken as a (mainly) non-participant observer. More specifically, I now identify this period as that of an "observer as trusted guest," building on trust initiated through shared colleagues, professional background and broad interests, alongside minor participatory teaching activities incorporated into most visits. Out of a large number of participants, 74 participants engaged with parts of the interview schedule designed for this study, outlined below. All participants progressed in their career from classroom teaching, including principals, headteachers and board of education members. Half of these (37) were current classroom teachers without a separate administrative position. Out of a large number of class and in-school observations, ten observations of moral education classes additionally allowed for reflective interviews with the teacher afterward. These interviews utilised the immediate concrete example of the prior class as a stimulus to discuss the interview questions in greater depth. $^{5}$

The semi-structured interviews in 2015 began with a discussion asking participants to consider school moral education in the broad sense. As background, participants responded to questions on what moral education is in Japanese schools, what values are learned/taught at school, and which are considered most important. (The results of this stage of the research are summarised above and reported elsewhere (Bamkin, 2016)). The data for this article were drawn from a second stage of the interviews. In reference to prior responses, participants considered how moral education is structured, and asked to provide examples of moral learning/teaching, and how these are planned. If not mentioned, participants were invited to discuss the role of moral education classtime. Follow-up questions included topics such as the degree to which moral education might influence children's behaviour outside school, and the counter-factual proposition of having no moral education classtime. Observations were used initially to generate critical perspectives on interview data, and to provide examples to illustrate the findings. Other data and interactions were utilised to aid interpretation. In particular, discussing documents, pedagogic dispositions and curriculum and lesson planning with teachers gave rise to new questions to further interview discussions.

The majority of interviews were conducted with elementary school educators. Whilst similarities and curriculum progression exist between elementary school and junior high school, assumptions about their nature are problematic because of differences both in patterns of work and in shared beliefs and practices, the latter of which has only recently become a focused subject of study. While elementary school practice has been characterised as nurturing, it is often claimed that junior high school teachers identify more closely with subject knowledge, and may express care with more severity (see Bjork, 2016; Cave, 2011, 2016; Shimahara, 2002). Structurally, the elementary school curriculum is taught almost entirely by one teacher per class-group, whilst most junior-high school subjects are taught by specialist subject-teachers. Moral education is taught by the homeroom teacher. At junior high school, the home-room teacher spends between two and five non-subject hours per week with their class group, plus (depending on various factors) some subject lesson time. On the other hand, junior high schools generally

${ }^{5} \mathrm{~A}$ full breakdown of the broader dataset can be found in Bamkin (2018, p. 84). 
provide substantial sports and bukatsu (club) activities. Thus, the academic and social relationships between teachers and students are differently configured. Insofar as the results here are generalizable, they should be confined to the elementary level.

\section{Learning as practice}

Out of participants who listed specific activities that contribute to moral education, the majority referred to cleaning, kakari responsibilities or serving and enjoying school lunch together. These activities, regarded as the primary means of moral education, are most commonly included under the curriculum section special activities. Sports and clubs (bukatsudō) at junior high level were also prominent. Pedagogies involving groupwork were also discussed. Less frequently, participants cited practices of agreeing on content for the class newsletter and agreeing on decisions such as class rules or the negotiation of new kakari responsibilities.

In Japanese schools, students are assigned responsibilities, including student-led lunch, cleaning, rotating duties of class monitor (nicchoku) and others listed in Table 1. For children who did not undertake similar responsibilities at preschool, many are incorporated into the daily routine of the class through the first months at school. Class rules are often established on the basis of discussion. At any given school, the results may be similar for most classes most years alongside idiosyncrasies, but are planned as a class group for children to feel agency in their selection.

Starting school

The first three weeks consist of half-days. Initially, children return home for lunch after a halfday of activities and class meeting. Children follow instructions on the organisation of belongings, packing up, and thinking about what items are needed the following day(s). School lunch begins during the third week, at which point children return home after lunch. For these days, the cleaning and school lunch service are undertaken by fifth- and sixth-grade children. First-grade children are hungry but unfamiliar with the routine and sit expectantly. A troupe of six sixth-grade children, wearing white aprons, hats and face-masks roll a wagon into the class, from which emerge trays, plates, serving wear and barrels of rice, soup and meat-vegetable mix. The teacher prompts the monitors to call the beginning of lunch, which they perform reading from a script. The teacher stands behind the two class monitors whispering prompts. The sixth graders bow and say goodbye, presumably to receive lunch from classmates in their own classroom.

The sixth graders reappear after lunch to pack up the wagon, though the teacher has already begun to do so, enlisting the help of first graders, and return it to the kitchen. After this, a group of fifth-graders then appear to lead the cleaning of the room. In one class meeting, the teacher leads a discussion on cleaning. Mentioning how the classroom is clean every day, the teacher prompts: Who was doing it? Who do we think has been cleaning the classroom for the past two weeks? The teacher wonders openly whether we could do it without the help of older children. The assumption that children/people want to do it themselves appears implicit. Within two days, the first graders are cleaning their rooms and serving lunch whilst the older children watch and help, coaching individual children at times. Later, sixth graders and the teacher accompany the first-grade group to fetch and later return the lunch wagon. Occasionally, the teacher draws attention to notices that include detailed descriptions of procedures - though the displays include pictures, the first graders are not yet such proficient readers. By the end of the fourth week, a duty rotation is established for first graders to serve their own lunch. 
Similar systems for older children to undertake lunchtime responsibilities for first graders at the beginning of the year are typical at elementary school, though varying in detail between schools and regions. Lewis (1995, p. 54ff) describes such activities as community building, building cohesion and unity between children, though their planned nature is not always apparent. Okihara, writing about school cleaning sees school community not only as a benefit of cleaning (Okihara, 1978, p. 23), but cleaning as an essential element of participatory democracy. Any notion that cleaning is the responsibility of the school and not pupils, he writes, suggests that children are not full members of the school (Okihara, 1978, p. 240). As the responsibility of the school, it should be conducted by children as members of the school. These activities are pedagogic in the sense that service and morally desirable practice in everyday school life are clearly planned. Both interest and the lure of gratitude in an atmosphere of goodwill are leveraged to build practices of cleaning and serving lunch.

The notion of service learning has provided theory for understanding pedagogies that include service in other contexts. Service learning is a family of theories that share a notion that values, virtues and prosocial sentiment, not necessarily only those related to work, can be partly or wholly learned through work itself, or through work-like activities. Early iterations of public service in US education considered learning through doing as an experimental practice-based pedagogy. Schachter (1998) reviewed proposals through the first two decades of the twentieth century, during which time committees suggested that "the way to teach civics ... is to give boys and girls 'chores' or tasks that compel them to feel for civic ideals - i.e. to discharge and not merely read about civic duties" (Schachter, 1998, p. 632).

Dewey makes an important contribution to the theory that is now called service learning. Dewey (1916) bridges ideas of experience and community to consider tasks, or responsibilities, framing democracy as a process of participation. In theorising the "school as a little society," Dewey begins with education as "life itself", ${ }^{6}$ as experienced by the individual child (Damon, 1997). This smaller community holds importance for the young child. Values, habits, practices and the regulation of emotions are constructed socially and mediated by a motivation to participate, and thus learned, in and through the community. Observations in the Japanese classroom reveal that these practices are established as part of the classroom routine. Most schools label time for class meetings, kakari, and some other special activities as "class activities" or "time for the school," emphasising its community-building function.

Japanese children are expected to come to recognise the benefits of special activities. However, pedagogical interventions contribute directly to encourage children's construction of a desire and will to participate. Indeed, children who do not participate are rarely compelled by threat of overt discipline. It is the warmth in the smiles of peers to whom they are serving food, and the invitation to the sense of achievement and fun from cleaning that remains a consistent part of the moral atmosphere, and generates goodwill and encourages participation. The handover of school lunch duties demonstrates the power of leveraging gratitude to encourage consideration of others, service and friendship as a social process amongst children. Moreover, it is pedagogically planned and

\footnotetext{
"Education is not preparation for life, but life itself" (Dewey, 1916).
} 
replicated, in similar ways, across schools and cohorts. In the lunch example, the moment when first-grade children come to see the older children cleaning is planned.

Through the first term, new responsibilities are established, many of which are similar between most classes. Responsibility is expanded to include as many children as possible. Some classes label all responsibilities kakari without differentiation; others designate creative examples with a different term, such as "company." Generally, kakari are undertaken by a group of two-to-four children for a period spanning anywhere between three months and the whole academic year. Duties, on the other hand, rotate on a daily or weekly basis, assigned to all children in equal quantity. Although not discussed here, responsibilities are also expanded from class activities to regular school-wide committee activities and temporary committees to manage school events. Table 1 provides a list of typical classroom kakari responsibilities, and some additional atypical creative examples proposed by children in classes observed in fieldwork. Special activities provide an example of how practice within a democratic classroom can be pedagogically planned in the taught curriculum. Indeed, the written curriculum has no requirement to involve

Table 1. Some examples of kakari responsibilities variously organised in elementary schools in Japan.*.

Commonly found responsibilities.

- Newsletter committee.

- Library committee.

- Wall display kakari. Rotating student work displayed on the classroom walls

- School environment and beautification.

- Health kakari. Keep an eye on others' safety, administer plasters, and accompany unwell or hurt classmates to the nurses room where required. Create posters. (Duties depend on level and age).

- PE. Leading warm-up exercises, encouragement, setting up equipment.

- Recycling.

- Announcements (school-wide).

Mainly elementary school

- Friend kakari. Noticing people who are playing alone and connecting them with games/activities.

- Rainy day kakari. Preparing games for rainy days.

- Classroom animal kakari (goldfish kakari, etc.).

Mainly junior high school

- School discipline committee.

- Student council (year-group, school, etc.).

Creative examples/temporary responsibilities

- Lights kakari.

- Heater brigade. Fetching kerosene from storage for the class heater during winter.

- Weather kakari. Searching the newspaper (usually available in the classroom or corridor table) for tomorrow's weather forecast and adding illustrations to tomorrow's schedule.

- Birthday card kakari. Making a birthday cards for each class members' birthday.

- Flower group. Brings in flowers for display in the classroom.

- Comic shopkeepers. Indexing comics drawn by classmates, and registering which are "on loan" behind a desk allocated as the comic shop.

- Trend cafe. Creates posters and gives presentations on fashions and popular characters, television programmes, etc.

- Comedy sketch writing and performance troupe.

- Greeting junior students at the start of the day.

Ongoing rotating duties

- Nicchoku class monitor, sometimes including chairing class meetings.

- Homework duty. Recording who has completed homework and collating it.

- Textbooks. Distributing textbooks for the following lessons.

- Blackboard cleaning.

- Collecting and distributing work.

- Keeping the classroom tidy.

- Administering the smooth running of routine study drills and quizzes, such as: kanji practice, reading-out-loud practice, vocabulary, arithmetic/maths exercises, etc.

*The structure of responsibilities and duties varies between classes and schools. The table is intended to provide a typical overview, alongside a flavour of the possibilities for creative examples. 
children in creating kakari, in involving higher grades in lunch or in creating the circumstances in which first graders desire to take (from those doing it) responsibility for cleaning the homeroom.

Given that special activities are seen as more prototypical of moral education, the value and purpose of moral education classtime can be questioned. Many participants considering moral education classtime were hesitant in responding to its contribution to everyday life. A common refrain was: "Moral education is about the heart [kokoro]..." As a deflecting response, this suggests a reluctance to endorse a direct influence on behaviour. A distinction emerged between notions of education with influence on behaviour and education of the "heart." Classtime educates the heart, but not practice or behaviour in everyday life (at least not directly), yet the latter is recognised as the ultimate goal of moral education. Nonetheless, some value is implicit in educating the "heart" through moral education classtime. The concept of the heart (kokoro) in the educational context has been described as an openness to being connected to others (Shimahara, 2002), and in Sato's (1998, p. 123) terms, "the centrepiece for self-development that places empathy and consideration of others as integral to self-identity." This is supported by my earlier finding (Bamkin, 2016) that teachers tend to place omoiyari as the top objective for moral education classtime. Omoiyari can be summarised as "consideration of others." However, the concept also suggests action in response to that sympathy $^{7}$ (Lebra, 1976).

"Education of the heart" may approach the will(ingness) to act, but does not necessarily cross the threshold into practice or behaviour. There was some consensus that: "moral education is not about teaching morality, but encouraging children to think about morality" (response by a classroom teacher). One head teacher explained during a presentation to parents that moral education classtime aims to develop: "thinking about the context of interactions, thinking about the perspective of others." Education of the heart is limited, it seems, in its uncertain capacity to influence everyday life, actions outside of school. This is not surprising to scholars of moral education. Blasi's (1980) critical review found that the rational understanding of moral dilemma scenarios is only a poor predictor of moral behaviour. It is possible to know one's mind on the preferred course of action, and yet not take it. This gap has been variously addressed by theories of moral development (for example, "moral courage" in business ethnics; "self-control" in Aristotelian character education). The taught curriculum in Japan addresses this gap by inviting children to willingly take responsibility and planning to "do together" as everyday practice, which may overlap with alternative solutions. Pedagogically it leverages gratitude, the warmth of being kind to others, achievement and fun to encourage the will(ingness) to participate.

At times, classtime is also used to practice speaking one's mind or undertaking the better course of action, as agreed by the class. One means of planning such practice is by role-playing the end of a story.

\footnotetext{
${ }^{7}$ Noddings (2013, p. xvi) has noted a preference in Western academia for the more cerebral "empathy" rather than the emotive "sympathy." The primarily intended meaning here is sympathy, with no intention to exclude empathy.
} 
Second-grade moral education class: "The broken ruler"

The teacher opens the lesson by asking whether anybody has heard a friend telling a lie, and known that that friend was lying. Many children raise their hands. Asking them to hold the idea, the teacher asks questions, "What were you thinking at that time?" Some responses are written on the board. One child says "tell the teacher." The teacher thanks the student but this response is not written on the board.

The teacher reads a simple story, which the children follow in the coursebook (Tokyo Shoseki, 2011, pp. 77-79). In summary, Haruto breaks a ruler which belongs to the class. He then calls over Taiyo and passes him the ruler, shouting out that Taiyo has broken the ruler. The main character, who remains an observer of the events, remembers that Haruto had previously broken something of his and blamed somebody else. Haruto's friends are watching and supporting him. The majority of the lesson is taken on considering (1) the situation of the broken ruler and spectators, (2) the feelings of Taiyo and (3) the main character (who is an observer). 1, 2 and 3 are organised in respective columns on the board, but addressed in discussion rather than chronologically. They consider: "What is the main character thinking?", "Who else is there, what are they doing?", "Why are they supporting Haruto?", "How does the main character feel at the end?" At one point the teacher says, "So the main character has nothing to do with this situation, so doing nothing would be OK [referring to a previous response from a child as recorded on the board]. But he thought that it was not right [referring to a previous response], and his heart is pounding [referring to previous responses on his feeling and to the jeers of Haruto's supporters]. The final question is, "What did the main character want to say [at the close of the story]?" The children have five minutes to write, which is enough time particularly because the lesson has followed a similar structure to previous moral education classes. After this, the teacher invites children to role-play what they have written, initially with a cast of two, then with the three characters. She had identified three different responses whilst roaming, and selected these three children in turn to play the main character. The class applauds after each. Finally, the teacher asks what everybody in the class thought when seeing the child say each response. "Why did Student A say, 'It's OK this time, but don't do the same thing again?'" The teacher summarises that "there are good things and bad things. When we see something, we need to think. And if we do something, other people will recognise it."

This lesson touches on basic issues of right and wrong. However, it is primarily about acting on conviction (courage) and self-management. As the teacher explains:

They know the difference between right and wrong. They knew [even] in first grade. So the story today was about breaking the ruler. They can see what is right and wrong. When we were reading the story, they were saying "that's mean." But then they wonder what to do. They suggest going to tell the teacher. In the story, the teacher is not there. That is quite close to what they think [in everyday school situations]. It is quite often ... you know. But we can't always do that. They can judge. They need to think. I'm sure they do [already], but they need to think and judge. The teacher is not here to tell them in each situation. And maybe they can practice that a little bit so that they can do what they think is best.

Other observations found children role-playing expressions of feelings in a story about friendship (Bamkin, 2016, pp. 10-11); and practicing to prompt a friend who is inappropriately speaking during a school ceremony.

Special activities, including meetings, kakari preparation and duties, have some time allocation but no overt lesson. Children's realisation of the learning objectives may be deferred, which one teacher likened to droplets of water dripping into a bowl which will someday overflow when they "realise something important" (the value of the activity). 
These activities are planned as opportunities to learn through work, motivated by planned leveraging of gratitude, desire for responsibility and the warm feeling of serving others. Teachers see these as one of the clearest groundings for moral education in Japanese classrooms. Lewis discusses spontaneous disagreements as "grist" for discussion toward learning, for example in class meetings. These social experiences with potential to underpin learning may also be pedagogically planned. Moral education classtime is mainly seen as important because of the way it interconnects with learning through practice in special activities and school life more generally. In the example above, classtime was used for structured practice of behaviour in a potentially socially threatening scenario. The following section examines how moral education classtime is planned to foster consideration of others, perseverance and the will to contribute.

\section{Classtime as a site for reflection}

Teacher participants, who overwhelmingly focused on special activities, were additionally invited to discuss moral education classtime. Classtime was framed as an opportunity to develop the will(ingness) to act or reflect on life, extending at least as far as school life. As one classroom teacher remarked:

"Developing the heart [studies in moral education classtime] does not necessarily lead to action. But as we are more active, moral education classtime can help us to understand these activities. Moral education is the base."

This suggests that children's understanding of why they are cleaning up, practicing kindness or persevering is important. The following example reflects on the value of keeping things tidy.

First-grade moral education class: Keeping things tidy

The teacher began by asking children to explain the term "keeping things tidy (seiriseiton)," listening to their explanations, which are then written on the board. The teacher then suggests they hear about Bam and Kero, dog and frog characters in a privately-published picture-book (Shimada, 1994) that she presents with a promising smile. Children anticipate the story, which they have not heard before. Each stage of the story is presented, elaborated from the pictures and text of the book, asking children how the characters feel, or what they might do next. They are encouraged to identify with Bam.

Bam and Kero have planned to play football outside, but this Sunday is a rainy day. Children are asked what he is thinking; can it be avoided; what might he do, etc. Bam thinks about inviting Kero to play inside, but his room is messy. The teacher asks the students various questions about the scenario, such as "What [mess] can you see? Why is it messy? What other things [problems] might happen in such a messy room? What is Bam going to do?" Bam prepares to clean up. Kero knocks at the door. Bam says he cannot play, but Kero offers to help Bam to tidy before playing. The teacher asks how each character might feel, and why Kero offered to help. Bam and Kero do tidying and cleaning. The teacher asks about what they are they doing, referring to the details of the tidying and the cleaning process in the pictures. Bam and Kero look at the tidy and clean room; the students are asked about what the characters are thinking. Children are supported in building ideas about Bam's and Kero's thoughts, which are listed on the board; the students are also asked why we should think about keeping things tidy. The teacher then asks the children how we can be careful to keep places tidy. Other students are asked to contribute how much they agree with each 
suggestion. The teacher writes "maybe" where consensus is not unanimous (for example, four children did not agree with "don't eat in the bedroom" as a rule. This was written with a "maybe").

The case of "Keeping things tidy" is relatively immediate for first-grade children. From the classrooms teacher's perspective: "it's not that they are asked to do something all of a sudden, but everybody [the children] are caught up in Bam's situation and want to tidy up." I interpreted this as an expectation that the children in the class vicariously will the character Bam to tidy up because they want him to be able to play with Kero. Not only the "positive" emotions of fun are drawn upon, but also the vicarious frustration through the children's identification with Bam contribute to the practice of tidying their desks. The reflective process of educating the "heart" is described as preparation. As one sixth-grade teacher commented: "Moral education [classtime] is thinking about weak points, dreams, reflection on actions. Less about attitude itself, and more realising." One experienced moral education teacher in a prefectural Education Office suggests that "developing a strong heart allows students to rise to the challenge."

Research in service learning suggests that service underpinned by curriculum content in class is more effective (Eyler \& Giles, 1999; McLellan \& Youniss, 2003) and where there is structured time for reflection (ibid; Niemi et al., 2000, p. 50). Nonetheless, McLellan and Youniss $(2003$, p. 55) suggests that service learning theory has not yet developed a means to differentiate between behaviour of service and their experiential counterparts. Given that contemporary US service learning typically aims to develop awareness of social justice and political activity (Schuitema et al., 2008, p. 73), McLellan and Youniss (2003) compared two activities theoretically associated with the "same issue" of poverty and hunger amongst the homeless. In one case, students collected donations of food for the homeless from middle-class neighbours. In the second case, they personally served food to homeless individuals. The study found that the latter experience invokes greater affect with greater capacity to augment will(ingness) toward further action than the first case. This was explained by the face-to-face nature of interactions "with unfamiliar homeless persons whose very appearance and demeanour could pose questions regarding poverty, government policy, and moral choices." The aims of moral education in the Japanese taught curriculum are practiced and discussed face-to-face with friends in the classroom community. Whilst almost all literature on US service learning draws on contexts above elementary age (Scott \& Graham, 2015, pp. 354-5), planned community activities taking the class as a little society suggests possibilities for more immediate pedagogically planned experiences for elementary-age children.

The distinction made in service learning theory between compulsory service and voluntary service may also be reduced by fostering the will(ingness) of children to participate in special activities. Students in Japan are rarely instructed directly to comply with special activities, which are experienced as part of school life (Lewis, 1995). Indeed, students who do not participate rarely receive direct sanctions, though less threatening disappointment or peer-reprimand is possible (Lewis, 1995; Tobin et al., 2009). Outside formal academic lessons, Japanese elementary teachers tend to work to reduce their presence in the classroom, proffering prompts, promoting support or challenges from other children, and potentially delaying assistance. Catherine Lewis (1989) draws on attribution theory (such as Lepper, 1983) to explain the power of this prevalent approach 
of Japanese teachers in the preschool and elementary classroom. Participant teachers tried to foster the internal motivation of children, occasionally waiting to introduce new kakari responsibilities until they thought that children would recognise the need for them. As explained above, prompting gratitude, empathy and other feelings is also planned at times, partly to foster willingness to take new responsibilities to manage themselves and the community.

\section{Sixth-grade moral education class: Mukai Chiaki}

The class read together and comprehend a story of the medical doctor and astronaut Mukai Chiaki's career (supplementary material elaborating MEXT, 2014, p. 20). Mukai trained hard, devoting many hours to study, to realise her dream of qualifying as a medical doctor. She realised her dream and began a successful practice as a heart surgeon and taught surgery at a famous university. At age 35 , she decided to train as an astronaut. The teacher encourages a small group discussion based on various questions: Why did she dream to become an astronaut? What is difficult about becoming an astronaut? How can she make it?, etc. Student contributions are listed on the board. The teacher picks keywords relating to dreams, drive and perseverance. The teacher explains that we can recognise our own strengths and work to extend them; and that realising our dreams requires perseverance, looking only at the goal we focus on. Students complete a reflective worksheet to identify "Who I am now," and "Who I wish to become."

Identifying with athletes who have persevered toward attainment aims to increase the students' will to persevere, which later forms into a habit or means to achieve. However, the classroom teacher wondered whether the lesson's impact was limited by the experience and demands of physical training. He suggests that it "might not be so meaningful to those who are not engaged in regular sports clubs. Though the understanding that follows may transfer to other [non-physical] things they try to do, too." The learning is firstly presented as domain-specific, but there is an aspiration that it could be generally applicable too. It aims to encourage refection on the demands and fruits of perseverance and following a dream with dedication. It exists as a potential tool to reflect on perseverance. Closely related to reflection, moral education classtime also serves as a framework, or point of reference, for teachers and children to draw upon during school life. Teachers may refer to the case of Mukai, for example, as encouragement to persevere at other times in school life.

The case of the moral thinking at work and its associated vocabulary are pre-learned, providing a point of reference that can be invoked when required. Similar observations of unplanned references to a framework developed in moral education classtime arose during fieldwork. In one such example, students had recently discussed the theme of "everybody's places (mina-no ba)" in moral education classtime. In that lesson, the class had agreed that these places included the park, the trees outside, the supermarket, the classroom, the gymnasium, time, the pool, stores and restaurants, etc. (mina-no kōen, mina-no ki, etc.). These are shared by members of the public from the perspective of the children. Some days after the lesson, the teacher was encouraging a student who was not participating in cleaning.

The third-grade teacher approaches a student who is not participating in cleaning and asks about the classroom. Whose responsibility is the cleaning of "everybody's classroom [minnano kyōshitsu]?" This seemed like an unnatural expression, but called to mind the earlier lesson on "everybody's places." In this sense it could be minna-no kyōshitsu. 
The event replicated language used in the earlier moral education class, encouraging the boy to contribute to the cleaning because of his membership in the classroom that is shared by "everybody."

Jackson and colleagues built on data collected in Midwest American schools in their work Moral life of schools (Jackson et al., 1993). Interpretation was consciously open, partly because of insufficient events that explicate moral principles. Despite the length and depth of this work of classroom ethnography, the authors find difficulty in attributing children's compliant behaviour to teaching. Passages such as the following are typical:

[Classroom teacher] Ms. Hamilton's comments to the children seated at tables three and five contain explicit moral instructions, including a rephrasing of the Golden Rule to fit the specific occasion. The children's compliance with her request raises a number of questions. Are they acting on principle? Do they understand and appreciate the basis of Ms. Hamilton's appeal for quiet? There is nothing in the observational record itself that would answer such questions, but we find it difficult to imagine the children responding chiefly to the rational force of Ms. Hamilton's words (Jackson et al., 1993, p. 58).

Jackson's work is more interested in the process of developing these questions than necessarily answering them. On occasions, the observations for this study provided the opportunity to observe not only discussion of moral principle and motivation, but also to affirm understanding, or at least analogy, through allusions to moral cases that had been discussed in moral education classtime. It is also consistent with previous observations (Lewis, 1995; Shimahara, 2002 at elementary school; Tobin et al., 2009 at preschool) that Japanese teachers are likely to explain inappropriate behaviour through lack of understanding. Though teachers may reference external or recent events in schools elsewhere, these examples demonstrates its planning in the taught curriculum. As one teacher explains: "I use the story at times for them, at any time. If they remember the story, it is possible to draw on it, or remember this character. I do it. The stories are just like what happens [in the class with those children] sometimes."

Moral education classtime is seen as a space to develop the "heart," for reflection on desirable practice, particularly in reference to special activities. It can at times generate a point of reference, or framework of knowledge, that can support discussions on behaviour elsewhere in school life. This reflection is cyclic and need not be conceptualised as preceding, anticeding or coinciding with special activities. Indeed, many special activities such as kakari responsibilities and rotating duties are daily and start at the beginning of school life, as does planned reflection on aspects of them.

\section{The role of the curriculum}

The taught curriculum in Japan is structured around its formal requirements. Teachers were required to supervise special activities and one hour per week of moral education classtime. Many of the means of implementing moral education are pedagogically planned, and intra-curriculum connections created, though neither is detailed in the written curriculum. The primary site for moral learning in special activities is designed for mainly incidental learning alongside reflection. Classtime provides space for this reflection and for pre-learning. Content is pre-learned, to an extent, but discovered experientially in school activities and everyday life. Experience provides "grist" for 
meaningful reflection. The relationship is cyclic. Though not discussed here, the curriculum structure also provides for integrated studies and physical education, which may provide further space for moral learning. Likewise, moral lessons are inevitably infused into subject lessons (see Cave, 2007 for a study of learning about self through subject lesson content).

US service learning literature tends to interpret "community" widely and usually in reference to activities outside of the school. Relatedly, it rarely addresses elementary education (Serriere et al., 2011, pp. 541-2). The curriculum discussed above incorporates pedagogies that can be interpreted through the concept of service learning. However, the examples show service toward classmates, focused primarily on the community in the classroom at elementary school. When expanded through junior high school, efforts are made to retain the community of the class. In the case of junior high school, activities undertaken for or with the wider community beyond the school gates are incorporated into variations of this structure. Interpersonal relationships are important to this pedagogy and operate through the class community. One theme running strongly through these examples is consideration of others.

Though moving away from the "how," and toward "what" is taught, the taught curriculum could be considered as one of caring. Care ethics, as expounded by Noddings (e.g. 2013), begins with relationships, and places priority on caring as a process of maintaining those relationships and as a fulfilling end in itself. Noddings devotes more discussion to promoting caring relationships between the teacher and children. ${ }^{8}$ It is clear, however, that Noddings believes that these contribute to caring relationships between children, partly through teaching by example. Here, the taught curriculum appears to focus more on building relationships between children, fostering caring children through the peer relationships which are forged through activities in the classroom community. Being cared for is accepted as a mode of being in a relationship. Children are fully human when cared for without an expectation for relationships to be reciprocal. For example, on the school lunch rotation children will always be served. But the process of education aims to empower children to expand their capacity, willingness and proactivity to care for others, from empathy to service (see Lewis, 1989). Further hallmarks of the care ethic include the focus of teachers on children's enjoyment, friendship and seemingly unconditional inclusion. The role of reasoning, for example, in the form of justice, is at times subordinated to emotion in the hope of instilling motivation (willingness) to accept responsibility and act within community norms (Noddings, 2002, p. 8).

This conception of the taught curriculum at Japanese elementary school is corroborated by evidence of both studies of spontaneous teaching at preschool and psychological tests of adolescents in Japan. At preschool, Tobin et al. (2009) juxtapose two examples of a teacher dealing with a particular mess caused by an identifiable child. In one example at a Japanese kindergarten, a boisterous child throws playing cards over the balcony. Another child tells the teacher, who responds by asking the child what "we" (members of the class) might do about it. Later that afternoon, the class tidies up and cleans together. In the other example at a preschool in Hawai'i, a boy leaves out a train set and becomes distracted doing

${ }^{8}$ Lewis also provides some discussion of the care provided by teachers in Japanese schools (e.g. Lewis, 1995, p. 149). 
something else. The boy is sent to "time out" until he tidies away the train set. A girl then emerges and goes to tidy away the train set. At this point, the teacher stops the girl from tidying up, deciding that the boy who was playing with it should tidy it away. She explains to the researcher that she is teaching him to tidy up his own toys because of a particular history with this child. Whilst caring and justice ethics may often coincide, this example demonstrates a preference for care ethics in the first example, and justice in the latter example. In the first example from Japan, the encouragement of community and kindness denies blame being apportioned and does not instruct the boy in tidying directly. In the second example from the US, ensuring that the "right" child tidies up denies the girl the opportunity to successfully offer kindness.

Care ethics is often compared with the Kohlbergian approach to moral education, which is based on justice ethics. In developing tests to measure presumed "stages" of moral development, Kohlberg uncritically incorporated a single model of ethics assumed to be universal. Specifically, he saw higher moral development to be characterised by the balancing of two competing rights under principles of justice. To the contrary, high levels of moral reasoning may more greatly value caring (Gilligan, 1977) through existing relationships (Noddings, 2013) or harmony over justice. They may seek pragmatic or context-dependent, rather than abstracted (purely principled) solutions to moral decisions. Iwasa's (2001) work was instrumental in the empirical demonstration that other well-developed ethical frameworks exist and can be culturally variable. Iwasa's study demonstrated a greater tendency amongst Japanese adolescents to challenge the confines of the scenario (also see Noddings, 2013, p. 105ff) and to consider additional values under a relational (caring) ethic, as opposed to justice ethics that attempts to balance competing abstracted rights.

The examples additionally demonstrate planning to encourage perseverance and selfmanagement. The training of perseverance, where planned, is directed toward the content of community activities, study, and helping others. However, in spontaneous teaching, it seems important as a value in itself. For example, one group of sixth-grade girls established a class responsibility (kakari or "company") to report on fashion trends and popular cartoon characters (kyarakutā). Though fashion is often seen as a flashpoint, potentially facilitating cliquiness, the teacher encouraged members to continue collecting new material to present once per week, and to renew the posters they created. Perseverance is encouraged even where caution is exercised in supporting the desirability of the subject matter or stated goal.

\section{Conclusion}

Because the Japanese curriculum includes classtime for moral education, it is easy to imagine that these classes serve as the primary vehicle for moral learning. Previous studies have made this assumption, resulting in an over-reliance on narrow sections of the written curriculum, and overlooking the process of implementation in practice. This study began with the broad conception of moral education to gain insight into the taught curriculum in Japan. It departs from previous studies in re-considering the role of the written curriculum, dedicated classtime, and the boundary between the planned and unplanned in classroom teaching. The findings shed light on the relationship between the narrow and broad senses of moral education in Japan. Whilst this approach considers the teachers' perspectives and planning for core areas of moral education, it overlooks the 
minutiae of everyday teaching practices and efforts made outside the curriculum "hotspots" identified by participants. In particular, the analysis focused on moral education classtime and special activities, which were raised by participants, rather than integrated studies or subject lessons. Discussions of physical education and extra-curricular "club" activities are also somewhat neglected due to both limited space and the limited scope of the dataset.

Documentary research on moral education policy, curriculum and textbooks constitutes a mature body of research. These studies are important to understand government intentions. However, they do not describe education practice on the ground, and treat moral education narrowly as classtime. This study provides further evidence that the study of public debate, policy, curriculum and textbooks is insufficient to understand how moral education is implemented in Japanese elementary schools. Moreover, taking a broad conception of moral education provides a more complete picture of the moral curriculum.

Separately, the findings indicate unexplored directions in pedagogic theory for moral education, drawing on data collected outside the Western Anglophone bubble. Service learning theory often sees service in relation to a community outside of the school. Could such a community, or little society, not be built inside the school, or classroom? Can moral education be planned through service activities such as lunch times and cleaning? Can teachers plan activities that invite children to adopt responsibilities in the classroom? Where is the ideal balance between reason and emotion in teaching values, and what issues arise? What kind of community atmosphere might be needed to facilitate such activities? These questions are focused on the how. It is acknowledged that responses may be impacted by what are seen to be the aims of moral education. In particular, there are times when demands of encouraging justice and encouraging caring diverge. Finally, there remain latent or underpinning qualities of democratic society in the classroom communities fostered at Japanese elementary school.

Beyond these findings, questions remain for a future study considering the effects of recent curriculum reforms to moral education. Key questions include: whether the autonomy of teachers to plan moral education classes has been reduced, either through the introduction of textbooks or by the requirement to create an annual syllabus ahead of time; whether the contents of textbooks has changed or narrowed; how formative, non-graded assessment reshapes teaching of moral education in Japan. Further questions on the connection of moral education classtime to students' lives, and changes in the perceived effectiveness or experience of teaching moral education may also follow. Such future studies will benefit from this baseline study analysing data collected immediately prior to any influences of the reforms.

\section{Disclosure statement}

No potential conflict of interest was reported by the author.

\section{Funding}

This research was supported by the award of a Churchill Fellowship (2015). I am also grateful to colleagues at the Curriculum Center for Teachers at Tokyo Gakugei University for further discussion, made possible by the award of a MEXT Research Scholarship (2018). 


\section{Notes on contributor}

Sam Bamkin is MEXT Research Scholar at the Graduate School of Education, University of Tokyo; and Adjunct Research Fellow at the Research and Clinical Center for Child Development, Hokkaido University. He is a Churchill Fellow (2015), Senior Fellow of the Higher Education Academy, and past participant of the Asia Studies Development Program (2014). He was previously Senior Lecturer in Education at De Montfort University, where he continues to teach as Visiting Lecturer. His main research projects consider how current reforms to moral education policy in Japan are being enacted locally in schools; and moral education and the implementation of education reform more generally.

\section{References}

Arthur, J., Kristjánsson, K., Harrison, T., Sanderse, W., \& Wright, D. (2016). Teaching character and virtue in schools. Routledge.

Aspinall, R. (2001). Teachers' unions and the politics of education in japan. SUNY Press.

Ball, S. (1994). Education reform: A critical and post-structural approach. Open University Press.

Ball, S. (2011). How schools do policy: Policy enactments in secondary schools. Routledge.

Bamkin, S. (2016). Moral education at Japanese elementary school. WCMT.

Bamkin, S. (2018). Reforms to strengthen moral education in Japan: A preliminary analysis of implementation in schools. Contemporary Japan, 30(1), 78-96. https://doi.org/10.1080/ 18692729.2018 .1422914

Bamkin, S. (2019). Moral education in Japan: The disjoint between research on policy and research on practice. Social Science Japan Journal, 22(2), 247-260. https://doi.org/10.1093/ssjj/jyz008

Berkowitz, M., \& Bier, M. (2005). What works in character education: A research-based guide for practitioners. Character Education Partnership.

Bjork, C., \& Fukuzawa, R. (2013). School guidance in Japanese middle schools. In G. DeCoker \& C. Bjork (Eds.), Japanese education in an era of globalisation (pp. 18-30). Teachers College Press.

Bjork, C. (2016). High stakes schooling. University of Chicago Press.

Blasi, A. (1980). Bridging moral cognition and moral action: A critical review of the literature. Psychological Bulletin, 88(1), 1-45. https://doi.org/10.1037/0033-2909.88.1.1

Bolton, K. (2015). Moral education in Japan: The coming of a new dawn. Unpublished MA thesis. University of Oslo. <https://www.duo.uio.no/>.

Cave, P. (2007). Primary school in Japan: Self, individuality and learning in elementary education. Routledge.

Cave, P. (2011). Explaining the impact of Japan's educational reform: Or, why are junior high schools so different from elementary schools. Social Science Japan Journal, 14(2), 145-163. https://doi.org/10.1093/ssjj/jyr002

Cave, P. (2016). Schooling selves: Autonomy, interdependence, and reform in Japanese junior high school. University of Chicago Press.

Damon, W. (1997). The child's world. Jossey-Bass.

Damon, W. (2008). Moral child: Nurturing children's natural moral growth. Simon and Schuster.

DeVries, R., \& Zan, B. (1994). Moral classroom, moral children. Teachers' College Press.

Dewey, J. (1916). Democracy and education. Macmillan. Available via WikiSource.

Eifuku, N. (2018). Gakushūshidōyōryō: Tokubetsu-no kyōka dōtoku-no ki-ni-naru [The curriculum: Caring about the special subject dōtoku]. Dōtoku-to tokubetsu-katsudō, 35(1), 36-37.

Eyler, J., \& Giles, D. (1999). Where's the learning in service-learning. Jossey-Bass.

Gilligan, C. (1977). In a different voice: women's conceptions of self and of morality. Harvard Educational Review, 47(4), 481-517. doi:10.17763/haer.47.4.g6167429416hg510

Giroux, H., \& Purpel, D. (Eds.). (1983). The hidden curriculum and moral education. McCutchan.

Hansen, D. (2001). Teaching as a moral activity. In V. Richardson (Ed.) Handbook of research on teaching (4th ed, pp. 826-857). Washington DC: American Education Research Association. 
Hoffman, S. D. (1999). School texts, the written words, and political indoctrination: A review of moral education curricula in modern Japan (1886-1997). History of Education, 28(1), 87-96. https://doi. org/10.1080/004676099284816

Iwasa, N. (2001). Moral reasoning of adults: Japan-US comparison. In H. Shimizu \& R. A. LeVine (Eds.), Japanese frames of mind (pp. 51-81). Cambridge University Press.

Jackson, P. (1992). Conceptions of curriculum and curriculum specialists. In P. Jackson (Ed.), Handbook of research on curriculum (pp. 3-40). MacMillan.

Jackson, P., Boostrom, R., \& Hansen, D. (1993). The moral life of schools. Jossey-Bass.

Kaizuka, S. (2009). Dōtoku no kyōkasho [Moral education textbooks]. Gakujutsu Shuppankai.

Kaizuka, S. (2016). Shūshin no rekishi [The history of Shūshin]. In M. Matsumoto, S. Kaizuka, M. Nishino, \& T. Gōda (Eds.), Tokubetsu no kyōka dōtoku Q\&A [Dōtoku special subject: Q\&A] (pp. 70-83). Mineruva.

Karasawa, T. (1955). Changes in japanese education as revealed in textbooks. Japan Quarterly, 2(3), 365-83.

Khan, Y. (1997). Japanese moral education past and present. Associated University Presses.

Kotera, M. (2016). Dōtoku no rekishi [History of moral education in Japan]. In M. Kotera \& H. Fujinaga (Eds.), Dōtoku kyōiku o manabu hito no tame ni (pp. 29-75). Sekaishisosha.

Lebra, T. (1976). Japanese patterns of behaviour. University of Hawai'i Press.

Lepper, M. (1983). Social control processes, attributions of motivation, and the internalization of social values. In E. T. Higgins, D. Ruble, \& W. Hartup (Eds.), Social cognition and social behaviour: Developmental perspectives (pp. 294-331). Jossey-Bass.

Lewis, C. (1989). From indulgence to internalization: Social control in the early school years. Journal of Japanese Studies, 15(1), 139-157. https://doi.org/10.2307/132411

Lewis, C. (1995). Educating hearts and mind. Cambridge University Press.

Lipsky, M. (1980). Street level bureaucracy. Russell Sage.

McLaughlin, M. (1987). Learning from experience: Lessons from policy implementation. Education Evaluation and Policy Analysis, 9(2), 171-178. https://doi.org/10.3102/01623737009002171

McLellan, J., \& Youniss, J. (2003). Two systems of youth service: Determinants of voluntary and required youth community service. Journal of Youth and Adolescence, 32(1), 47-58. https://doi. org/10.1023/A:1021032407300

MEXT. (2008). Shōgakkō/Chūgakkō gakushūshidōyōryō [National curriculum].

MEXT. (2014). Watashi-tachi no dōtoku. Shögakkō 5ロ6nen [Our virtue. 5th and 6th grades]. Monbukagakushō. <http://www.mext.go.jp/a_menu/shotou/doutoku/detail/1344254.htm>

MEXT. (2015). Shōgakkō/Chūgakkō gakushūshidōyōryō [National curriculum, including amendments for moral education special subject].

MEXT. (2017). Shōgakkō/Chūgakkō gakushūshidōyōryō [National curriculum].

Nakano, A. (1989). Gendai no dōtoku kyōiku [Moral education in modern Japan]. Kokusai Kyōiku Jōhō Sentā.

Niemi, R., Hepburn, M., \& Chapman, C. (2000). Community service by high school students. Political Behavior, 22(1), 45-69. https://doi.org/10.1023/A:1006690417623

Nishimura, H. (2016). Gakkō-ni okeru dōtoku-no zentaikōsō [the broad conception of moral education at school]. In M. Kotera \& H. Fujinaga, Dōtoku kyōiku o manabu hito no tame ni (pp. 141215). Sekaishisosha.

Nishino, M. (2017). The challenge of developing meaningful curriculum initiatives for moral education in Japan. Journal of Moral Education, 46(1), 46-57. https://doi.org/10.1080/03057240.2016. 1276438

Noddings, N. (2002). Educating moral people. Teachers College Press.

Noddings, N. (2013). Caring: A relational approach to ethics and moral education (2nd ed.). University of California Press.

Okihara, Y. (1978). Gakkō sōji: Sono ningenkeisei-teki yakuwari [School cleaning: Its role in character formation]. Gakuji Shuppan.

Poukka, P. (2011). Moral education in the Japanese primary school curricular revision at the turn of the twenty-first century [PhD thesis]. University of Helsinki. Also published as Department of Teachers' Education Research Report, 323. Helsinki: University of Helsinki. 
Roesgaard, M. (2016). Moral education in Japan: Values in a global context. Routledge.

Rohlen, T. (1983). Japan's high schools. University of California Press.

Sanger, M., \& Osguthorpe, R. (2005). Making sense of approaches to moral education. Journal of Moral Education, 34(1), 57-71. https://doi.org/10.1080/03057240500049323

Sato, M. (1998). Classroom management in Japan: A social history of teaching and learning. In N. Shimahara (Ed.), Politics of classroom life: Classroom management in international perspective (pp. 189-214). Garland.

Schachter, H. (1998). Civic education: Three early American political science association committees and their relevance for our times. Political Science \& Politics, 31(3), 631-635. https://doi.org/10. $1017 /$ S1049096500054998

Schuitema, J., Ten Dam, G., \& Veugeers, W. (2008). Teaching strategies for moral education: A review. Journal of Curriculum Studies, 40(1), 69-89. https://doi.org/10.1080/00220270701294210

Scott, K., \& Graham, J. (2015). Service-learning: implications for empathy and community engagement in elementary school children. Journal of Experiential Education, 38(4), 354-372. https://doi. org/10.1177/1053825915592889

Serriere, S., Mitra, D., \& Reed, K. (2011). Student voice in the elementary years: Fostering youth-adult partnerships in elementary service-learning. Theory and Research in Social Education, 39(4), 541-575. https://doi.org/10.1080/00933104.2011.10473466

Shimada, Y. (1994). Bamu to Kero no nichiyōbi [Bam and Kero's Sunday]. Bunkeido.

Shimahara, N. (2002). Teaching in Japan: A cultural perspective. Psychology Press.

Tanaka, M. (2010). Nihon no Dōūtoku kyōiku no hensei [the formation of moral education]. In T. Yoshida, M. Tanaka, \& K. Hosoda (Eds.), Dōtoku kyōiku no hensei to kadai: 'kokoro'-kara 'tsunagari'-e [Formation and issues in moral education: From 'hearts' to 'connections']. (pp. 152). Gakumonsha.

Tobin, J., Hsueh, Y., \& Karasawa, M. (2009). Preschool in three cultures revisited. University of Chicago Press.

Tokyo Shoseki (2011). Minna tanoshiku dotoku. Tokyo Shoseki. 